\title{
Effect of different simulated metal dusting environments on austenitic Alloys 602CA and 800
}

\author{
FML Mulaudzi ${ }^{1,2,3, a}$, LA Cornish ${ }^{1,2, b}$, GA Slabbert ${ }^{3,4, c}$, SJ Moema ${ }^{3, d}$, MJ Papo $^{2,3, e}$
}

\author{
'School of Chemical and Metallurgical Engineering, University of the Witwatersrand, \\ ${ }^{2}$ DSI-NRF Centre of Excellence in Strong Materials, hosted by the University of the Witwatersrand, Johannesburg, South Africa, \\ ${ }^{3}$ Advanced Materials Division, Mintek, Randburg, South Africa, \\ ${ }^{4}$ Metallurgical Engineering Department, Sasol-Synfuels, Secunda, South Africa \\ Email:amarandelam@mintek.co.za, blesley.cornish@wits.ac.za, cdeon.slabbert@sasol.com, djosephm@mintek.co.za, ejonesp@mintek.co.za
}

\begin{abstract}
Metal dusting processes and associated filamentous carbon formation were studied on austenitic Alloys 602CA and 800 after exposure to $18.9 \% \mathrm{CO}-79.1 \% \mathrm{H}_{2}-2 \% \mathrm{H}_{2} \mathrm{O}$ and $25 \% \mathrm{CO}-70 \% \mathrm{H}_{2}-5 \% \mathrm{H}_{2} \mathrm{O}$ (vol.\%) gas mixtures at $650{ }^{\circ} \mathrm{C}$. The alloys were studied by visual examination, optical microscopy, scanning electron microscopy with energy dispersive X-ray spectroscopy (SEM-EDX), Raman spectroscopy and X-ray diffraction (XRD). Alloy 602CA was more resistant to metal dusting than Alloy 800. SEM imaging of the surfaces showed that Alloy 800 suffered metal attack at $168 \mathrm{~h}$, whereas Alloy 602CA suffered minor attack only after $336 \mathrm{~h}$. Coke deposits increased on Alloy 800 with increased exposure, and there was little coke deposited on Alloys 602CA from after $336 \mathrm{~h}$. Raman spectroscopy confirmed graphite by the characteristic D- and G-peaks.
\end{abstract}

Keywords: Metal dusting, Alloy 602CA, Alloy 800, Raman spectroscopy, X-ray diffraction

\section{Introduction}

Metal dusting is a severe form of corrosion attack in which iron, steels, Ni- and Co-based alloys disintegrate into metal or metal carbide particles in coke when exposed to strongly carburising gases (carbon activity $a_{\mathrm{C}}>1$ ) at $300-800^{\circ} \mathrm{C}$ (Chun et al., 2003; Zhang et al., 2003). Chromium-containing alloys can form a protective chromia $\left(\mathrm{Cr}_{2} \mathrm{O}_{3}\right)$ scale to resist metal dusting attack. Oxide scales on high alloy steels and Ni-based alloys form a protective layer during the exposure period (Röhnert et al., 2007). However, extensive chromium carbide $\left(\mathrm{Cr}_{3} \mathrm{C}_{2}, \mathrm{Cr}_{23} \mathrm{C}_{6}\right)$ precipitation depletes chromium such that the protective chromia scale is not maintained, and allows metal dusting to occur (Röhnert et al., 2007). The metal dusting of these alloys is normally in the form of hemispherical and localized pitting where the original material transforms into a fine dust or coke of graphite and nanocrystalline-sized oxide particles (Szakálos, 2004). The mechanisms leading to metal dusting depend on the substrate material (e.g. Fe, Ni, Ni-based alloys, austenitic and ferritic steels) (Röhnert et al., 2007). Metal dusting occurs in many petrochemical processes and so is of great significance to these industries because of costly replacement of the metal dusted plant components and the associated downtime, which also results in financial losses. Metal dusting also affects production efficiencies leading to reduction in production yields (Gunawardana et al., 2012; Lei et al., 2009; Melo-Máximo et al. 2013; Müller-Lorenz and Grabke 1999; Voisey et al., 2006a; Voisey et al., 2006b; Zeng and Natesan, 2007).

Metal dusting corrosion occurs in environments with carbon activity $a_{\mathrm{c}}>1$, and gaseous reactions that cause metal dusting are (Grabke et al., 2007):

$$
\begin{array}{ll}
\mathrm{CO}+\mathrm{H}_{2}=\mathrm{C}+\mathrm{H}_{2} \mathrm{O} & a_{\mathrm{c}}=\mathrm{K}_{1} \cdot P_{\mathrm{CO}} \cdot P_{\mathrm{H} 2} / P_{\mathrm{H} 2 \mathrm{O}} \\
2 \mathrm{CO}=\mathrm{C}+\mathrm{CO}_{2} & a_{\mathrm{c}}=\mathrm{K}_{2} \cdot P_{\mathrm{CO}}^{2} / P_{\mathrm{CO} 2} \\
\mathrm{CH}_{4}=\mathrm{C}+2 \mathrm{H}_{2} & a_{\mathrm{c}}=\mathrm{K}_{3} \cdot P_{\mathrm{CH} 4} / P_{\mathrm{H} 2}^{2}
\end{array}
$$

where $\mathrm{K}$ is an equilibrium constant, and $\mathrm{P}$ is partial pressure of the different species in the gas.

In this study, samples were exposed to different simulated metal dusting gas mixtures $\left(18.9 \mathrm{vol} \% \mathrm{CO}-79.1 \mathrm{vol} \% \mathrm{H}_{2}-2 \mathrm{vol} \% \mathrm{H}_{2} \mathrm{O}\right.$ and $25 \mathrm{vol} \% \mathrm{CO}-70 \mathrm{vol} \% \mathrm{H}_{2}-5 \mathrm{vol} \% \mathrm{H}_{2} \mathrm{O}$ ) at $650^{\circ} \mathrm{C}$ with different carbon activities and oxygen partial pressures, Equation 1. The carbon activities were enough to cause metal dusting (Chun et al., 2003; Zhang et al., 2003). The initial study in $18.9 \mathrm{vol} \% \mathrm{CO}-79.1 \mathrm{vol} \% \mathrm{H}_{2}-$ $2 \mathrm{vol} \% \mathrm{H}_{2} \mathrm{O}$ showed that environment was not particularly aggressive to the alloys (Mulaudzi et al., 2011; Mulaudzi et al., 2012), so a more aggressive environment of $25 \mathrm{vol} \% \mathrm{CO}-70 \mathrm{vol} \% \mathrm{H}_{2}-5 \mathrm{vol} \% \mathrm{H}_{2} \mathrm{O}$ was attempted to be able to study the effects better.

In the initial study of Alloys 602CA and 800 in $18.9 \% \mathrm{CO}-$ $79.1 \% \mathrm{H}_{2}-2 \% \mathrm{H}_{2} \mathrm{O}$ (Mulaudzi et al., 2011; Mulaudzi et al., 2012), Alloy 602CA was more resistant to metal dusting than Alloy 800 . Alloy 602CA had different colours on the surface with different exposure times from $24 \mathrm{~h}$ until after $168 \mathrm{~h}$, attributed to changes in surface layer thickness. After $336 \mathrm{~h}$ and $720 \mathrm{~h}$ exposures, there were small amounts of coke deposits, but no metal dusting. Alloy 800 was similar, but coke deposits started after $96 \mathrm{~h}$ and $168 \mathrm{~h}$, with increased amounts. After $720 \mathrm{~h}$ exposure, there was also some metal dusting on the edges, and pits.

SEM on the surface of Alloy 602CA showed a phase in the matrix before exposure (Mulaudzi et al., 2011; Mulaudzi et al., 2012), with 
Table 1: Summary of the phases on the surfaces and in coke deposits identified by X-ray diffraction on Alloy 800 after different exposures (Mulaudzi et al., 2011; Mulaudzi et al., 2012)

\begin{tabular}{lll}
\hline Alloy & Exposure & Phases \\
\hline & $\begin{array}{l}\text { Before exposure, } \\
24 \mathrm{~h} \text { and } 96 \mathrm{~h}\end{array}$ & $(\gamma \mathrm{Fe}, \mathrm{Ni})$ \\
$168 \mathrm{~h}$ & $\begin{array}{l}(\gamma \mathrm{Fe}, \mathrm{Ni}), \mathrm{Fe}_{2} \mathrm{O}_{3} \\
\text { Surface: }(\gamma \mathrm{Fe}, \mathrm{Ni}) ; \\
\text { Coke deposit: Graphite, } \\
(\gamma \mathrm{Fe}, \mathrm{Ni}), \mathrm{Fe}_{3} \mathrm{O}_{4}\end{array}$ \\
& $336 \mathrm{~h}$ & $\begin{array}{l}\text { Surface: }(\gamma \mathrm{Fe}, \mathrm{Ni}), \mathrm{Fe}_{2} \mathrm{O}_{3} ; \\
\text { Coke deposit: } \mathrm{Graphite}, \\
(\gamma \mathrm{Fe}, \mathrm{Ni}), \mathrm{Fe}_{3} \mathrm{O}_{4}\end{array}$ \\
\hline
\end{tabular}

little change after $24 \mathrm{~h}$ exposure at $650^{\circ} \mathrm{C}$. After $96 \mathrm{~h}$ exposure, a new phase started to develop on the surface, and after $168 \mathrm{~h}$ exposure, it had become distinct white precipitates, which were too small to analyse. After $336 \mathrm{~h}$ exposure, filamentous carbon formed, and after $720 \mathrm{~h}$ exposure there was dark protrusions. Alloy 800 before exposure showed an unattacked rough alloy surface. After $24 \mathrm{~h}$ and $96 \mathrm{~h}$ exposures, there were uniformly deposited platelets on the surface, and after $168 \mathrm{~h}$ the amount increased, starting to form a scale layer on the surface. After $336 \mathrm{~h}$, the surface had high amounts of deposited platelets, as well as small white precipitates, and after $720 \mathrm{~h}$, the surface had uniformly distributed light precipitates.

Optical microscopy showed Alloy 602CA after $24 \mathrm{~h}$ exposure had annealing twins with carbides precipitated in the grains (Mulaudzi et al., 2011; Mulaudzi et al., 2012). After 96 h, 168 $\mathrm{h}$ and $336 \mathrm{~h}$ exposures, there was a "hatching effect" within the grains caused by the dark precipitates precipitating within the matrix, and allotriomorphic carbides precipitated in the grains and grain boundaries. There was a uniform protective oxide scale layer on the surface after $96 \mathrm{~h}$ and $168 \mathrm{~h}$. After $336 \mathrm{~h}$, there was direct inward growth of graphite on the grain boundaries, and the grain boundaries were attacked due to the further carbon diffusion from the environment through the grain boundaries. After $720 \mathrm{~h}$ exposure, there was some inward attack along the grain boundaries, and fewer allotriomorphic carbides. There was still a uniform protective oxide scale on the surface. Alloy 800 before and after 24 $\mathrm{h}$ exposure showed annealing twins. After $96 \mathrm{~h}$ exposure, the alloy had a thin oxide layer on the surface, whereas after $168 \mathrm{~h}$, there was some carbide precipitations. After $336 \mathrm{~h}$ and $720 \mathrm{~h}$ exposure at $650^{\circ} \mathrm{C}$, optical microscopy showed the alloy had thicker grain boundary precipitates.
X-ray diffraction (XRD) of Alloy 602CA after different metal dusting exposures showed only austenite $(\gamma \mathrm{Fe}, \mathrm{Ni})$, whereas Alloy 800 had only austenite $(\gamma \mathrm{Fe}, \mathrm{Ni})$ until after $96 \mathrm{~h}$, where there was also iron oxides (Mulaudzi et al., 2011; Mulaudzi et al., 2012). Phases on the surfaces and in coke deposits identified by XRD on Alloy 800 after different exposures are summarised in Table 1. Raman spectroscopy confirmed the existence of nano-crystalline graphite in the coke deposit showing graphite's D- ( 1320 Raman shift $\left.\left(\mathrm{cm}^{-1}\right)\right)$ and G- $\left(\sim 1600\right.$ Raman shift $\left.\left(\mathrm{cm}^{-1}\right)\right)$ peaks (Ferrari et al., 2000; Guo et al., 2021; Reich et al., 2004; Röhnert et al., 2007).

\section{Experimental procedure}

Metal dusting studies were carried out on Alloys 602CA and 800 coupons (compositions shown in Table 2) in two environments for 24, 96, 168, 336 and $720 \mathrm{~h}$ exposure times (Table 3).

For metallography, the reacted specimens were first $\mathrm{Cu}$-plated to protect the metal dusted surface, then mounted in a Polyfast conductive resin for SEM analysis and in diallylphthalate for optical microscopy. The mounted specimens were ground to 1200 grit using $\mathrm{SiC}$ papers, and then polished with diamond cloth to a 1 $\mu \mathrm{m}$ surface finish. Optical microscopy samples were etched with 1 part $\mathrm{HNO}_{3}+4$ parts $\mathrm{HCl}+1$ part $\mathrm{H}_{2} \mathrm{O}_{2}$ solution. Afterwards, the samples were studied by visual examination, optical microscopy, scanning and transmission electron microscopy with energy dispersive X-ray spectroscopy (SEM- and TEM-EDX), Raman spectroscopy and X-ray diffraction (XRD).

\section{Results}

Alloys $602 \mathrm{CA}$ and 800 were exposed in the $25 \% \mathrm{CO}-70 \% \mathrm{H}_{2}-$ $5 \% \mathrm{H}_{2} \mathrm{O}$ metal dusting environment at $650^{\circ} \mathrm{C}$. An optical micrograph of Alloy 602CA after $168 \mathrm{~h}$ exposure showed a bluish colour on the surface, as shown in Figure 1a. Alloy 602CA after 336 h exposure had coke deposits on the surface, Figure 1b. After coke removal, there was no sign of major metal degradation, only very fine pits at the edges. After $720 \mathrm{~h}$ exposure, there were coke deposits on the surface (Figure 1c). Alloy 800 after $168 \mathrm{~h}$ exposure had a greenish colour, and there was some coke deposited on the surface, as shown in Figure 1d. After $336 \mathrm{~h}$ and $720 \mathrm{~h}$ exposures, there were coke deposits on the surfaces, as shown in Figures 1e and 1f. After coke removal, there was major metal degradation due to much pitting at the edges and a little pitting on the main surface.

Optical microscopy of the cross-sections of Alloy 602CA after 168 $\mathrm{h}, 336 \mathrm{~h}$ and $720 \mathrm{~h}$ exposures showed allotriomorphic carbides had precipitated in the grains and on grain boundaries, Figures 2a-2c. There was some coke precipitated on the grain boundaries Figure

Table 2: Nominal compositions of commercial Alloys 602CA and 800 (wt\%) (Lai, 2007)

\begin{tabular}{lcccccccc}
\hline \multirow{2}{*}{ Alloy } & \multicolumn{7}{c}{ Elements (wt\%) } \\
\cline { 2 - 9 } & $\mathbf{C}$ & $\mathbf{C r}$ & $\mathbf{N i}$ & $\mathbf{F e}$ & $\mathbf{A l}$ & $\mathbf{T i}$ & $\mathbf{Y}$ & $\mathbf{Z r}$ \\
\hline $602 \mathrm{CA}$ & 0.20 & 25.0 & Bal. & 10.0 & 2.1 & 0.15 & 0.09 & 0.06 \\
800 & 0.05 & 21.0 & 32.5 & Bal. & 0.38 & 0.38 & - & - \\
\hline
\end{tabular}

Table 3: Experimental parameters of the simulated metal dusting environments

\begin{tabular}{lccc}
\hline Input gas compositions (vol.\%) & Temperature $\left({ }^{\circ} \mathbf{C}\right)$ & Carbon activity & Oxygen partial pressure (atm) \\
\hline $18.9 \% \mathrm{CO}-79.1 \% \mathrm{H}_{2}-2 \% \mathrm{H}_{2} \mathrm{O}$ & 650 & 11.75 & $4.35 \times 10^{-26}$ \\
$25 \% \mathrm{CO}-70 \% \mathrm{H}_{2}-5 \% \mathrm{H}_{2} \mathrm{O}$ & 650 & 5.50 & $3.47 \times 10^{-25}$ \\
\hline
\end{tabular}




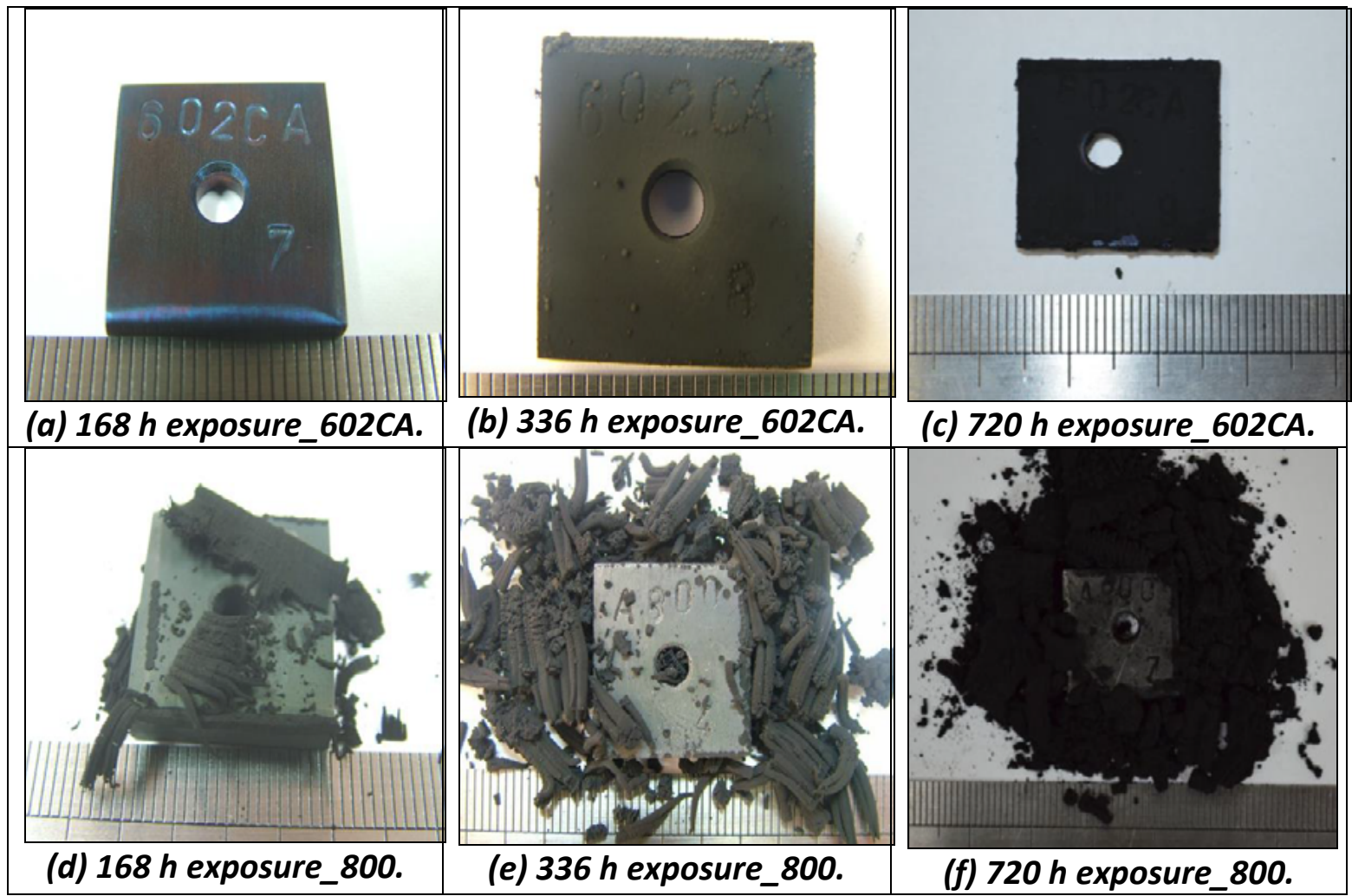

Figure 1: Photographs of Alloys 602CA and 800 coupons after different exposures

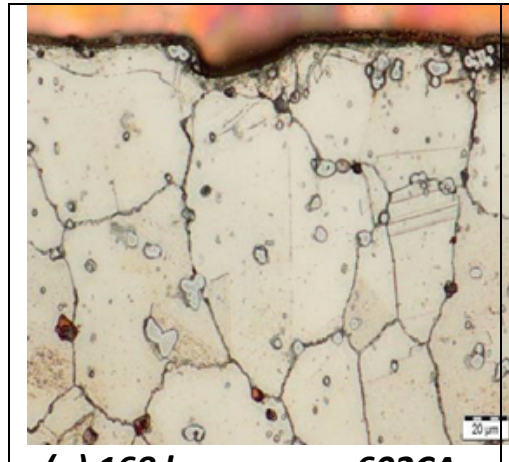

(a) $168 \mathrm{~h}$ exposure_602CA.

(b) $336 \mathrm{~h}$ exposure_602CA.

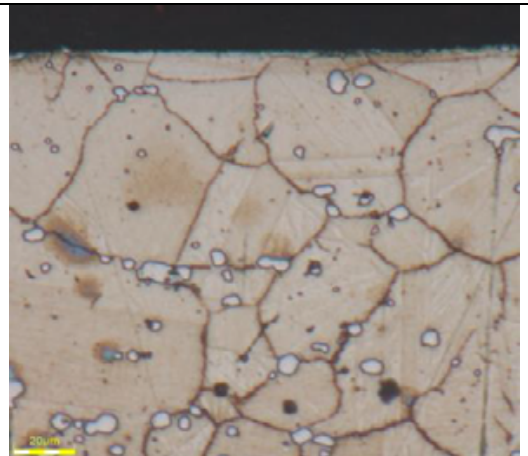

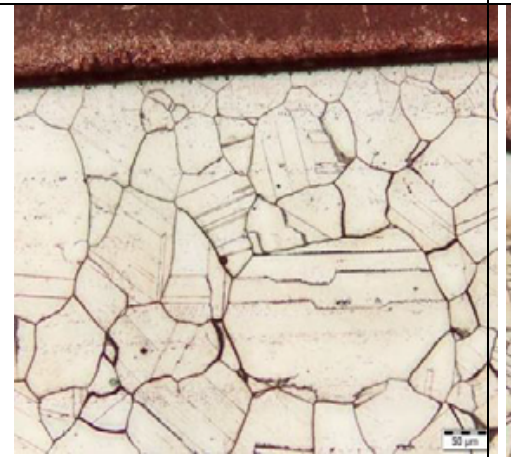

(d) $168 \mathrm{~h}$ exposure_800.

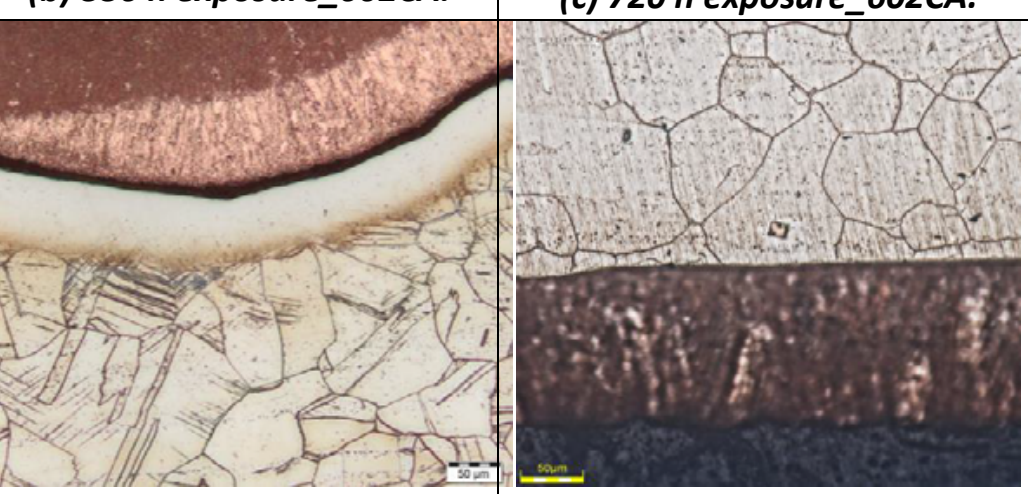

(e) $336 \mathrm{~h}$ exposure_800.

(f) 720 h exposure_800.

Figure 2: Optical micrographs of cross-sections of Alloys 602CA and 800 after different exposures, showing: (a-c) Alloy 602CA with allotriomorphic carbides precipitated in the grains and on grain boundaries, and (d-f) Alloy 800 with precipitation on parallel crystallographic planes, some more annealing twins, with pitting and a dark layer

2a. Optical microscopy image of Alloy 800 after $168 \mathrm{~h}$ exposure showed there was graphite growing on the grain boundaries (Figure 2d), and after $336 \mathrm{~h}$, there was precipitation on parallel crystallographic planes, some more annealing twins, with pitting and a dark layer on the surface (Figure 2e). The coke deposits on the annealing twins were closely associated with those on the grain boundaries. After $720 \mathrm{~h}$ exposure, there was a dark layer on the surface (Figure 2f). 
Table 4: Summary of the phases on the surfaces and in coke deposits identified by X-ray diffraction on Alloys $602 \mathrm{CA}$ and 800 after different exposures

\begin{tabular}{|c|c|c|}
\hline Alloy & Exposure & Phases \\
\hline \multirow{3}{*}{ 602CA } & Before exposure, $24 \mathrm{~h}, 96 \mathrm{~h}$ and $168 \mathrm{~h}$ & $(\gamma \mathrm{Fe}, \mathrm{Ni})$ \\
\hline & $336 \mathrm{~h}$ & $(\gamma \mathrm{Fe}, \mathrm{Ni}),(\alpha \mathrm{Fe}, \mathrm{Cr})$, graphite \\
\hline & $720 \mathrm{~h}$ & $(\gamma \mathrm{Fe}, \mathrm{Ni}), \mathrm{Fe}_{2} \mathrm{O}_{3}, \mathrm{Fe}_{3} \mathrm{O}_{4}$, graphite \\
\hline \multirow{5}{*}{800} & Before exposure & $(\gamma \mathrm{Fe}, \mathrm{Ni})$ \\
\hline & $24 \mathrm{~h}$ and $96 \mathrm{~h}$ & $(\gamma \mathrm{Fe}, \mathrm{Ni}),(\alpha \mathrm{Fe}, \mathrm{Cr})$ \\
\hline & $168 \mathrm{~h}$ & $\begin{array}{l}\text { Surface: }(\gamma \mathrm{Fe}, \mathrm{Ni}),(\alpha \mathrm{Fe}, \mathrm{Cr}) \text {; } \\
\text { Coke deposit: Graphite, }(\gamma \mathrm{Fe}, \mathrm{Ni}), \mathrm{Fe}_{3} \mathrm{O}_{4}, \mathrm{Fe}_{3} \mathrm{C}\end{array}$ \\
\hline & $336 \mathrm{~h}$ & $\begin{array}{l}\text { Surface: }(\gamma \mathrm{Fe}, \mathrm{Ni}),(\alpha \mathrm{Fe}, \mathrm{Cr}), \mathrm{Cr}_{23} \mathrm{C}_{6} \\
\text { Coke deposit: Graphite, } \mathrm{Fe}_{3} \mathrm{O}_{4}\end{array}$ \\
\hline & $720 \mathrm{~h}$ & $\begin{array}{l}\text { Surface: }(\gamma \mathrm{Fe}, \mathrm{Ni}), \mathrm{Fe}_{2} \mathrm{O}_{3}, \mathrm{Fe}_{3} \mathrm{O}_{4} \text {; } \\
\text { Coke deposit: Graphite, } \mathrm{FeNi}_{3}, \mathrm{Fe}_{3} \mathrm{O}_{4}\end{array}$ \\
\hline
\end{tabular}

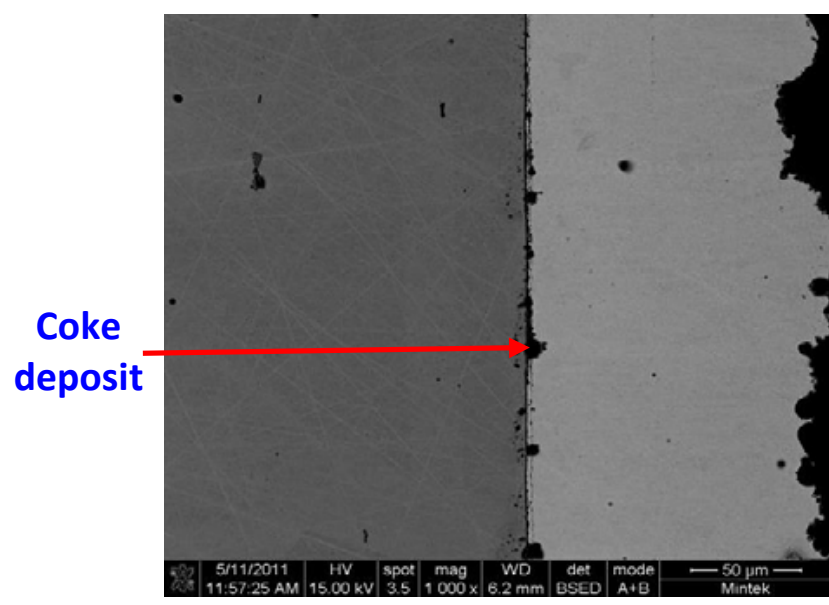

(a)

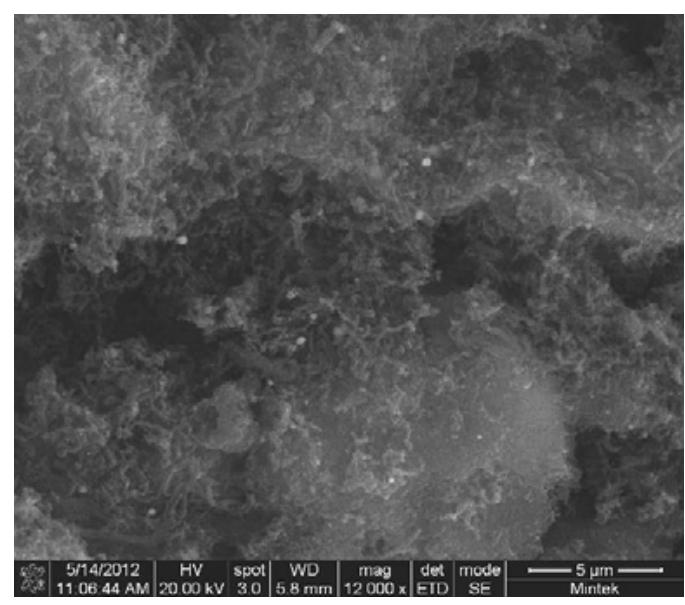

(b)

Figure 3: SEM-BSE and SEM-SE images of cross-section and coke deposits of Alloy 800 after 336 h exposure, showing: (a) coke deposited on the surface, and (b) coke with light contrast metal particles (Mulaudzi et al., 2011; Mulaudzi et al., 2012)

Table 4 summarises the phases on the surfaces and in coke deposits of Alloys $602 \mathrm{CA}$ and 800 which were identified by X-ray diffraction after different exposure times. Raman spectroscopy confirmed the nano-crystalline graphite in the coke deposit showing graphite's D- ( 1320 Raman shift $\left.\left(\mathrm{cm}^{-1}\right)\right)$ and G- $\left(\sim 1600\right.$ Raman shift $\left.\left(\mathrm{cm}^{-1}\right)\right)$ peaks (Ferrari et al., 2000; Guo et al., 2021; Reich et al., 2004; Röhnert et al., 2007).

\section{Discussion}

The carbon activities were more than unity, which resulted in metal dusting (Zhang et al., 2003). Oxygen partial pressure encouraged the formation of metal oxides (Meschter and Grabke, 1979; Münster and Grabke, 1980). The effect of pressure was not studied, since the rig was only safety-tested for atmospheric pressure, but lower pressure is not expected to cause more metal dusting than higher pressure (Szakálos et al., 2002a; Szakálos et al., 2002b). However, the slower metal dusting of the less severe (18.9\%CO$79.1 \% \mathrm{H}_{2}-2 \% \mathrm{H}_{2} \mathrm{O}$ ) experimental environments allowed the earlier stages to be observed, like the surface carbon deposition and graphite growing on the grain boundaries, eventually causing metal degradation.

In the earlier study, $18.9 \% \mathrm{CO}-79.1 \% \mathrm{H}_{2}-2 \% \mathrm{H}_{2} \mathrm{O}$ with calculated carbon activity 11.75 and $4.35 \times 10^{-26}$ atm oxygen partial pressure (Mulaudzi et al., 2011; Mulaudzi et al., 2012), Alloy 602CA had better resistance against metal dusting than Alloy 800. Alloy 602CA had much less coke deposition and much less pitting. After exposure Alloy 800 formed unstable cementite $\left(\mathrm{Fe}_{3} \mathrm{C}\right)$, as identified by Grabke (Grabke et al., 2007), which involved carbon transfer and deposition, where carbon diffused from the environment, and resulted in oversaturation of the alloy matrix. The formation of $\mathrm{Fe}_{3} \mathrm{C}$ at the surface and at grain boundaries produced a diffusion barrier for further carbon ingress, causing nucleation of graphite on the surface, as shown in Figure 3a. The $\mathrm{Fe}_{3} \mathrm{C}$ became unstable and decomposed, allowing the inwards growth of graphite. The graphite deposit grew into the $\mathrm{Fe}_{3} \mathrm{C}$, resulting in more carbon deposition from the gas phase, often under the growth of carbon filaments (Figure 3b) from the metal particles (Szakálos, 2004). The synthesis gases, $\mathrm{CO}_{2}$ and $\mathrm{CO}$, in the simulated metal dusting environment resulted in graphite formation on the surface of the Alloy 800, and started the disintegration of the surface by inwards graphitization.

In $25 \% \mathrm{CO}-70 \% \mathrm{H}_{2}-5 \% \mathrm{H}_{2} \mathrm{O}$, with calculated carbon activity 5.50 and $3.47 \times 10^{-25} \mathrm{~atm}$ oxygen partial pressure, Alloy 800 had more coke deposits than Alloy 602CA. Alloy 800 had pitting on the surface due to $\mathrm{Cr}_{23} \mathrm{C}_{6}$ precipitation there (Figure 2d), which depletes chromium from the matrix, resulting in the chromia scale not being maintained, and allowing metal dusting to occur (Röhnert et al., 2007), whereas Alloy 602CA had $\mathrm{Cr}_{3} \mathrm{C}_{2}$ carbide precipitation, 


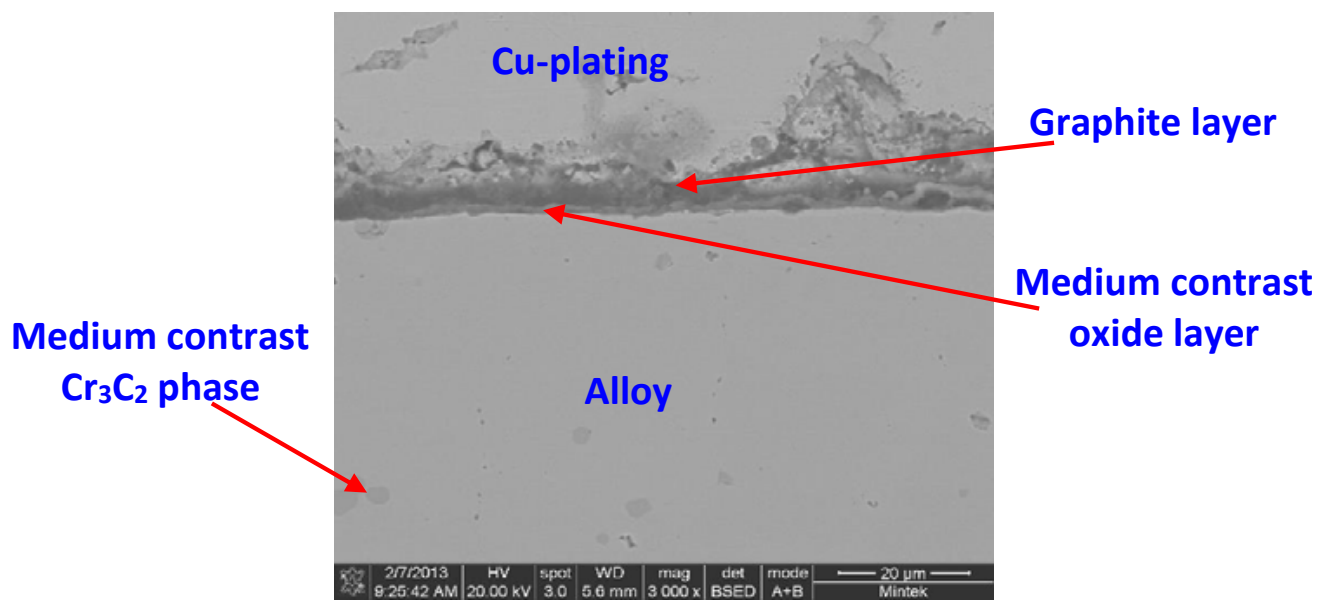

Figure 4: SEM-BSE image of cross-section of Alloy 602CA after $168 \mathrm{~h}$ exposure, showing: medium contrast $\mathrm{Cr}_{2} \mathrm{O}_{3}$ oxide layer, medium contrast $\mathrm{Cr}_{3} \mathrm{C}_{2}$ phase and graphite layer on the surface

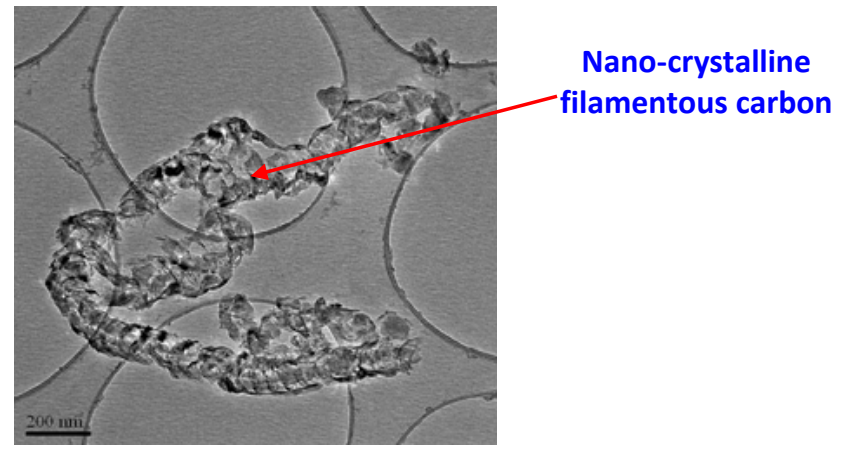

Figure 5: TEM image of coke deposited on Alloy 800 after $336 \mathrm{~h}$ exposure, showing nano-crystalline filamentous carbon

which removed less chromium from the matrix (Figure 4) giving a more protective $\mathrm{Cr}_{2} \mathrm{O}_{3}$ layer, which protected the alloy better (Röhnert et al., 2007). The environment with the lower carbon activity $\left(a_{\mathrm{c}}=5.50\right)$ and more CO gave more severe metal dusting than with higher carbon activity $\left(a_{\mathrm{c}}=11.75\right)$ and less CO. Alloy 800 had more metal dusting products than in the other environment.

TEM of the coke deposited on Alloy 800 (Figure 5) revealed nanocrystalline graphite in the coke deposit, which was confirmed by Raman spectroscopy, with graphite's D- ( 1320 Raman shift $\left.\left(\mathrm{cm}^{-1}\right)\right)$ and G- $\left(\sim 1600\right.$ Raman shift $\left.\left(\mathrm{cm}^{-1}\right)\right)$ peaks (Ferrari et al., 2000; Guo et al., 2021; Reich et al., 2004; Röhnert et al., 2007).

X-ray diffraction of Alloy $602 \mathrm{CA}$ in the $18.9 \% \mathrm{CO}-79.1 \% \mathrm{H}_{2}-$ $2 \% \mathrm{H}_{2} \mathrm{O}$ environment identified only austenite $(\gamma \mathrm{Fe}, \mathrm{Ni})$ (Mulaudzi et al., 2011; Mulaudzi et al., 2012), similar to $25 \% \mathrm{CO}-70 \% \mathrm{H}_{2}$ $5 \% \mathrm{H}_{2} \mathrm{O}$ until after $168 \mathrm{~h}$ exposure, whereas after $336 \mathrm{~h}$ exposure, there were $(\gamma \mathrm{Fe}, \mathrm{Ni})$, ferrite $(\alpha \mathrm{Fe}, \mathrm{Cr})$ and graphite, and after 720 $\mathrm{h}$, there were $(\gamma \mathrm{Fe}, \mathrm{Ni}), \mathrm{Fe}_{2} \mathrm{O}_{3}, \mathrm{Fe}_{3} \mathrm{O}_{4}$ and graphite. In $18.9 \% \mathrm{CO}-$ $79.1 \% \mathrm{H}_{2}-2 \% \mathrm{H}_{2} \mathrm{O}$, XRD of Alloy 800 identified $(\gamma \mathrm{Fe}, \mathrm{Ni})$, iron oxides $\left(\mathrm{Fe}_{2} \mathrm{O}_{3}\right.$ and $\left.\mathrm{Fe}_{3} \mathrm{O}_{4}\right)$ and graphite (Mulaudzi et al., 2011;
Mulaudzi et al., 2012). In $25 \% \mathrm{CO}-70 \% \mathrm{H}_{2}-5 \% \mathrm{H}_{2} \mathrm{O}$ environment, $\mathrm{XRD}$ on Alloy 800 identified $(\gamma \mathrm{Fe}, \mathrm{Ni})$ and $(\alpha \mathrm{Fe}, \mathrm{Cr})$ on the surfaces until after $336 \mathrm{~h}$. Coke deposits comprised graphite, $\mathrm{Fe}_{3} \mathrm{C}$ and iron oxides $\left(\mathrm{Fe}_{2} \mathrm{O}_{3}\right.$ and $\left.\mathrm{Fe}_{3} \mathrm{O}_{4}\right)$ phases.

Table 5 shows the effect of different alloying elements on metal dusting of Alloys 602CA and 800. The slightly higher chromium and aluminium contents for Alloy 602CA than Alloy 800 gave better resistance against metal dusting, as shown in Figure 1, where Alloy 602CA had much less coke deposits (Figures 1b-c), than Alloy 800 (Figures 1c-f), which also had pitting (Figure 2d). The titanium contents for the two alloys were very similar. These differences in compositions contributed to their metal dusting mechanisms.

The reaction kinetics of Alloys 602CA and 800 in the $18.9 \% \mathrm{CO}$ $79.1 \% \mathrm{H}_{2}-2 \% \mathrm{H}_{2} \mathrm{O}$ and $25 \% \mathrm{CO}-70 \% \mathrm{H}_{2}-5 \% \mathrm{H}_{2} \mathrm{O}$ environments are shown in Figure 6. In $18.9 \% \mathrm{CO}-79.1 \% \mathrm{H}_{2}-2 \% \mathrm{H}_{2} \mathrm{O}$ (Figure 6 , labelled as 1), there was no discernable mass change for Alloy 602CA from $24 \mathrm{~h}$ to $720 \mathrm{~h}$ exposure, agreeing with the lack of coke deposition (Mulaudzi et al., 2011; Mulaudzi et al., 2012), and no major attacks. Conversely, there were large mass changes for Alloy 800 from $336 \mathrm{~h}$ exposure, because of the coke deposits, as well as grain boundary attack (Mulaudzi et al., 2011; Mulaudzi et al., 2012). In $25 \% \mathrm{CO}-70 \% \mathrm{H}_{2}-5 \% \mathrm{H}_{2} \mathrm{O}$ (Figure 6, labelled as 2), there were mass changes Alloy 800 starting from $24 \mathrm{~h}$ exposure, albeit with high errors. Alloy 800 also experienced metal losses after 96 $\mathrm{h}$ due to pitting, with increased loss after $336 \mathrm{~h}$ exposure. There was no metal loss for Alloy 602CA until after $168 \mathrm{~h}$ exposure, and little evidence of metal degradation. There was higher mass change for both alloys in $25 \% \mathrm{CO}-70 \% \mathrm{H}_{2}-5 \% \mathrm{H}_{2} \mathrm{O}$ than in $18.9 \% \mathrm{CO}$ $79.1 \% \mathrm{H}_{2}-2 \% \mathrm{H}_{2} \mathrm{O}$, although Alloy $602 \mathrm{CA}$ was the best alloy, and would be preferred in these environments.

Table 5: Effects of different alloying elements on metal dusting of Alloys 602CA and 800

\begin{tabular}{ccccc}
\hline \multirow{2}{*}{ Alloy } & \multicolumn{3}{c}{ Alloying elements (wt\%) } & \multicolumn{2}{c}{ Performance } \\
\cline { 2 - 5 } & $\mathbf{C r}$ & $\mathbf{A l}$ & 0.15 & Better \\
\hline $602 \mathrm{CA}$ & 25.0 & 2.1 & 0.3 & $\mathrm{Bad}$ \\
\hline 800 & 21.0 & 0.3 & & 0.3 \\
\hline
\end{tabular}




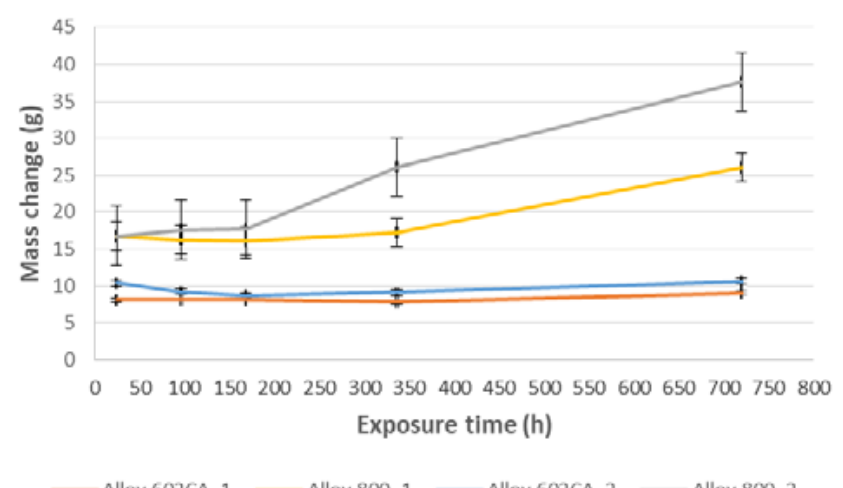

Figure 6: Mass changes of Alloys 602CA and 800 in $18.9 \% \mathrm{CO}-79.1 \% \mathrm{H} 2-2 \% \mathrm{H} 2 \mathrm{O}$ (labelled as 1 ) and $25 \% \mathrm{CO}-70 \% \mathrm{H} 2-5 \% \mathrm{H} 2 \mathrm{O}$ (labelled as 2 ) after different exposure times

\section{Conclusions}

Alloys 602CA and 800 were investigated under two different simulated metal dusting environments $\left(18.9 \% \mathrm{CO}-79.1 \% \mathrm{H}_{2}-\right.$ $2 \% \mathrm{H}_{2} \mathrm{O}$ and $25 \% \mathrm{CO}-70 \% \mathrm{H}_{2}-5 \% \mathrm{H}_{2} \mathrm{O}$ ) at $650{ }^{\circ} \mathrm{C}$ under atmospheric pressure (1 bar), with calculated carbon activity of 11.75 and 5.50, and oxygen partial pressure of $4.35 \times 10^{-26} \mathrm{~atm}$ and $3.47 \times 10^{-25} \mathrm{~atm}$.

Metal dusting was by $\mathrm{Fe}_{3} \mathrm{C}$ layer formation, which then disintegrated due to graphite formation. Carbon diffused from the environment, and oversaturated the metal matrix. The $\mathrm{Fe}_{3} \mathrm{C}$ became unstable and decomposed into graphite and metal particles. $\mathrm{The} \mathrm{Cr}_{23} \mathrm{C}_{6}$ precipitates allowed localized pitting, because of $\mathrm{Cr}$ depletion of the matrix. Thus, precipitation of $\mathrm{Cr}$-rich carbides prevented the alloy from re-forming protective oxide scales because the chromium in the carbides was immobilized, and unable to diffuse in the alloy, form oxides and passivate it.

The chromia- and alumina-forming Alloy 602CA resisted metal dusting better than Alloy 800 in the $18.9 \% \mathrm{CO}-79.1 \% \mathrm{H}_{2}-2 \% \mathrm{H}_{2} \mathrm{O}$ and $25 \% \mathrm{CO}-70 \% \mathrm{H}_{2}-5 \% \mathrm{H}_{2} \mathrm{O}$ simulated metal dusting environments, because of the higher chromium and aluminium contents, which resulted in the formation of protective $\mathrm{Cr}_{2} \mathrm{O}_{3}$ and $\mathrm{Al}_{2} \mathrm{O}_{3}$ scales.

\section{Acknowledgements}

This paper is published with the permission of Mintek. The assistance of Mintek and Department of Science and Innovation (DSI) through Advanced Materials Initiative Ferrous Metals Development Network (AMI-FMDN) is gratefully acknowledged.

\section{References}

1. Chun CM, Mumford JD, Ramanarayanan TA. 2003. Metal Dusting Corrosion of Cobalt. Journal of the Electrochemical Society 150, 2 , B76-B82.

2. Ferrari AC, Robertson J. 2000. Interpretation of Raman Spectra of Disordered and Amorphous Carbon. Physical Review B 61, 20, 95-107.

3. Grabke HJ, Schütze M. 2007. Corrosion by Carbon and Nitrogen (Metal Dusting, Carburization and Nitridation), Woodhead Publishing Limited, Cambridge, England.

4. Gunawardana PVDS, Walmsley J, Holmen A, Chen D, Venvik HJ. 2012. Metal Dusting Corrosion Initiation in Conversion of Natural Gas to Synthesis Gas. Energy Procedia 26, 125-134.

5. Guo X, Vanhaecke E, Vullum PE, Ma J, Daham PV, Gunawardana S, Walmsley JC, Chen D, Venvik HJ. 2021. Effects of Metal Dusting Relevant Exposures of Alloy 601 Surfaces on Carbon Formation and Oxide Development. Catalysis Today 369, 48-61.

6. Lai GY. 2007. High-Temperature Corrosion and Materials Applications. ASM International, Materials Park, Ohio, USA.

7. Lei N, Zhou C, Hu G, Chen C. 2009. Thermodynamic Analysis of Metal Dusting on Iron in CO-H2-H2O Atmosphere. Journal of Natural Gas Chemistry 18, 222-224.

8. Melo-Máximo L, Salas O, Melo-Máximo D, Oseguera J, López-Hitara VM, Torres RD, Lepienski CM, de Souza RM. 2013. Performance of Cr Oxide Coatings on 304 Steel Against Metal Dusting. Surface and Coatings Technology 237, 39-50.

9. Meschter P, Grabke HJ. 1979. Kinetics of the Water-Gas Shift Reaction on An „FeO“ Surface. Metallurgical Transactions B 10 , 323-329.

10. Mulaudzi FML, Cornish LA, Slabbert GA and Papo MJ. 2011. A Study of Metal Dusting on Alloys 602CA and 800. ZrTa2011 New Metals Development Network Conference, 13th-14th October, 14-Mulaudzi on CD.

11. Mulaudzi FML, Cornish LA, Slabbert GA and Papo MJ. 2012. A Study of Metal Dusting on Alloys 602CA and 800. The Journal of the Southern African Institute of Mining and Metallurgy 112, No. 7A, 589-600.

12. Müller-Lorenz EM, Grabke HJ. 1999. Coking by Metal Dusting of Steels. Materials and Corrosion 50, 614-621.

13. Münster P, Grabke HJ. 1980. Berichte Bunsenges für Physikalische Chemie 84, 1068-1071.

14. Reich S, Thomsen C. 2004. Raman Spectroscopy of Graphite. Philosophical Transactions of the Royal Society A 362, 2271-2288.

15. Röhnert D, Phillipp F, Reuther H, Weber T, Wessel E, Schütze M. 2007. Initial Stages in the Metal-Dusting Process on Alloy 800 Oxidation of Metals 68, 271-293.

16. Szakálos P, Liu L. 2002a. Mechanisms of Metal Dusting - Application to Alloy Composition. Temperature and Pressure, 15th International Corrosion Conference (ICC), Paper 806, Granada, 22-27 September.

17. Szakálos P. 2002b. Testing of Intermetallics in Metal Dusting Conditions. SIMR Report IM-2002-536.

18. Szakálos P. 2004. Mechanisms of Metal Dusting. PhD Thesis, Royal Institute of Technology and Swedish Institute for Metals Research, Stockholm, Sweden.

19. Voisey KT, Liu Z, Stott FH. 2006a. Inhibition of Metal Dusting of Alloy $800 \mathrm{H}$ by Laser Surface Melting. Applied Surface Science 252, $10,3658-3666$

20. Voisey KT, Liu Z, Stott FH. 2006b. Inhibition of Metal Dusting Using Thermal Spray Coatings and Laser Treatment. Surface and Coatings Technology 201, 3-4, 637-648.

21. Zeng Z, Natesan K. 2007. Control of Metal Dusting Corrosion in Ni-based Alloys. International Journal of Hydrogen Energy 32, 16, 3640-3647.

22. Zhang J, Schneider A, Inden G. 2003. Characterisation of the Coke formed during Metal Dusting of Iron in CO-H2-H2O Gas Mixtures. Corrosion Science 45, 1329-1341. 